\title{
Putting Foucault to Work in Tourism
}

\author{
Research
}




\section{Keywords}

Foucault; applied discourse theory; tourism and heritage research; post structuralism; discursive analytic 


\begin{abstract}
This paper reflects on Foucault's archaeology of knowledge as a methodological approach in tourism research. It offers lessons from recent research focused on critiquing heritage sites and museums as examples of destination discourse. The aim is $n$ to tackle an increasingly acknowledged reluctance to declare method when carrying out Foucauldian analysis. The paper reflects on the role of discourse analysis as a methodology in tourism research before considering Foucault's specific contribution. It then offers a synthesis of Foucault's methodological ideas and presents these as an adaptable discursive analytic which can be applied to a range of tourism research contexts. It considers the methodological limits that are associated with the deployment of Foucault before a conclusion considers the novel contribution of the paper, which is an adaptable discursive analytic for tourism researchers to contemplate when thinking about how to 'do' Foucauldian discourse analysis.
\end{abstract}

\title{
1. Introduction
}

Developments over recent decades in areas such as textual linguistics and, more broadly, in the interdisciplinary study of discourse offer great potential in terms of their application to analyses of a range of research contexts where the aim is to understand the uses and implications of texts. As part of this movement, discourse analysis that follows the work of Michel Foucault has evolved as a useful methodology in specific enquiry, in disciplines such as healthcare (Fadyl et al, 2013) but also in cultural studies and tourism (see O'Donnell and Spires, 2012, and Wight 2016). However, there are conflicting views about what counts as 'Foucauldian' when it comes to methods and methodology. This paper derives from research into museums and heritage sites approached as destination 'texts' using a form of Foucauldian discourse analysis to understand how objects of discourse come to be produced and maintained within the wider social construct of the tourism destination. The purpose of the paper, and what makes it a productive contribution to the field is to tackle the much publicised issue of how one should go about 'doing' a Foucauldian discourse analysis to open up the possibility for tourism researchers to use Foucault, rather than simply discuss his ideas. The paper examines the perceived dangers and taboos in adopting Foucault in primary tourism research by offering a methodological synthesis of his seminal 
quasi-methodological work Archaeology of Knowledge in order to equip tourism researchers with a modus operandi for undertaking post-structuralist research to critique truth and power in tourism contexts.

The paper addresses a perceived reticence amongst scholars (and scholarly critics) of Foucault to 'declare method' for fear of appearing to be prescriptive (Sarup, 1993). It challenges another perception within the literature; that adopting a Foucauldian approach necessitates the production of what is often considered an inaccessible language of terminologies, which emanates from an unapproachable and overcomplicated philosophical realm. The challenges and methodological weaknesses associated with applying Foucault are therefore discussed in some detail. It is argued that, as Graham (2005) notes, it is unlikely that Foucault would have wished to bequeath a poisoned chalice to the academic community, and at some stage researchers who engage with his work must challenge themselves to outline methodological possibilities. This paper suggests one such methodological possibility, and to achieve this it considers the work of others who have already made convincing intellectual commitments to the application of Foucault within primary research such as Graham (2005), O'Donnell and Spires (2012) and Wight (2016). The outcome is an accessible and adaptable discursive analytic based on a synthesis of Foucault's seminal post-structural writing which provides tourism researchers with a clear orientation to his ideas in a tourism context, and an avenue to developing a practical research strategy to apply to tourism situations. The methodological limitations to Foucauldian discourse analysis are also discussed.

The paper begins with a discussion of manifestations of discourse analysis in tourism research using recent and varied examples from the literature. It then introduces Foucault's methodological approach and relates this broadly to studies of tourism. It goes on to tackle some of the problems that are associated with deploying Foucault in an essentialist way within social scientific and humanities research before providing a contextualised orientation to Foucault's Archaeology of Knowledge, which is widely regarded as his only attempt to speak to methodology. Finally, it suggests a discursive analytic (a research strategy for doing discourse analysis) that sets out how tourism researchers might go about satisfying a range of research agendas using Foucauldian thinking. The impetus for the 
paper is to make discourse analysis more routinely accessible to tourism researchers in order to empower those that are inspired to reach beyond the typical interdisciplinary business approaches associated with tourism research, and the fetishized analytical tools of questionnaires, SPSS and interviews which enable these. In so doing, the paper responds to Tribe's (2005), still salient criticism of tourism research in noting that it tends to follow a template. It also answers his call for research that demonstrates an innovative theoretical and methodological approach. It addresses Cheong and Miller's (2000) concern that only a small number of scholars in the field of tourism studies have deployed Foucauldian reasoning to tourism research, and only in much generalized, and often inaccessible ways. The implications for the management of tourism relate to how academics and practitioners can understand the role of cultural 'surfaces of emergence' (spaces in which meanings arise in tourism) such as attractions, museums and guidebooks in shaping destination discourses. Such institutions can be approached using a Foucauldian lens as 'discursive spaces' in which ideas are produced which favour particular narrative versions at the expense of others. As Hollinshead (1999) puts it, tourism studies require a means to monitor and challenge the subordination of people through tourism narratives. Tourism is a knowledge generating, and power-producing form of consumerism which therefore deserves to be critiqued using novel research methodologies such as the one proposed in this paper. 


\section{Discourse Analysis in Tourism}

Discourse analysis of the type explored here can make more explicit the classical approaches that are associated with content analysis. It can also underpin a research paradigm within tourism studies that views textual analysis not only as a research method-for example, in critiques of museum and heritage narratives (see Hooper-Greenhill, 1989) -but also as an autonomous endeavour towards the construction of a sound theory of tourism discourse which can be useful for critiquing texts in tourism. 'Text' in this sense refers to the broad linguistic definition that Titscher et al (2000) describe as any communicative utterance, practice or event that may be narrative, instructive descriptive or argumentative. It is useful as a preamble to considering Foucauldian thinking in tourism to examine how discourse analytical methodologies more broadly have hitherto been deployed in tourism research. Discourse is an increasingly fashionable term (Jorgensen and Philips, 2002), yet one that is often used innocently without the essential accompaniment of an adequate definition. Discourse analysis does not describe a single analytical framework, but a number of interdisciplinary approaches that can be put to use in research in a variety of social spheres (Fairclough, 1992). Naturally, any attempt to advocate for an objective definition is futile, and there is much to divide the philosophical underpinnings of the available approaches to take when 'doing' discourse analysis for research purposes. However, one idea that offers some unity is the idea that discourse analysis is concerned with a certain way of talking about, and indeed representing the world. In addition, it is useful to consider that discourse analysis is not simply a method, but an holistic approach to research that is led by a philosophical premise, a theoretical model and a methodological strategy. Typically, the theory and methods are intertwined such that the researcher must identify with a particular theoretical perspective in order to deploy discourse analysis as a research strategy (Johnstone, 2008).

Discourse analysts carry out a process which is common to us all in routine daily life; to notice patterns within language use. However, the discourse analyst goes about this systematically, methodologically, and philosophically by examining the specific circumstances in which language is deployed (Grenz, 1996). As a methodological approach, discourse analysis is typically recognised as being part of applied linguistics, but it does not belong exclusively to this field since it is diversely applied to a range of interests (Paltridge, 
2006). A wide range of theories and techniques can be drawn from to study language in use in various source disciplines including linguistics, psychology, pragmatics, sociology and anthropology (Trappes-Lomax, 2008). Whatever the approach, discourse analysis combines interests in the rules, principles, contexts and functions of language. A number of approaches to discourse analysis are notable in the literature. For example, Berdychevsky et al's (2016) carried out an analysis of the socially constructed female tourist experience in North America based on a 'language in use' approach to discourse. Guedes and Jimenez (2016) reported on a phenomenological analysis of packaged tourism discourses in Portugal. Stepchenkova and Zhan (2013) carried out a content analysis of destination images of Peru, and Choi, Lehto and Morrison (2007) studied the constructed image of Macau on travel related websites.

What is common to these approaches is the methodological deployment of Critical Discourse Analysis (CDA), which is multifarious and draws from a wide variety of theoretical backgrounds. CDA uses terms such as 'politics', 'ideology' and 'power' based on various, often mercurial definitions which necessitate identification with a specific school of thought for clarity and context. CDA is undertaken using a range of philosophical, abstract approaches to critique such issues as identity, dominance and resistance, and the configuration and deployment of language in particular social and cultural contexts including various tourism contexts. Relevant here are Van Dijk's (1993:283) arguments about the role of discourse in maintaining dominance. He defines dominance as the '...exercise of social power elites, institutions or groups that results in social inequality, including political (and) cultural (inequality).' As Konstanje (2018) and Frew and White (2013) remind us in the context of tourism, history and heritage are selectively designed, and the narratives that are sold at any given time are privileged at the expense of others that remain invisible. Indeed, although heritage can have a role in reinforcing a national ethos, the identity that it reinforces is based on a sense of spectacle and selective memory (Guidotti-Hernandez, 2011). In terms of the analysis of such selectivity in tourism representations, Tzanelli (2017) suggests that privileging one particular register of meaning is unproductive. Rather, the discourse analyst should critique attempts to produce alternative languages that privilege one cultural register over others. Relevant here is Plantenkamp and Botterill (2013) suggestion that memorialisation, as a construction of 
various communities and their pasts must be managed as a subtle dialogue where no groups remain voiceless.

Analyses of the structures and strategies of discourse are not particularly common in tourism research, perhaps because of a perceived reluctance amongst researchers to abandon the convenience and safety of following a prescriptive research approach (Graham, 2005), and also because of what Tribe (2005) describes as a crystallisation of tourism studies around interdisciplinary business approaches, and an increasingly held view of the world of tourism as a technically rational, economic phenomenon. This would suggest that tourism studies are at an important intersection marked by the arrival of 'new' tourism research, which is defined by a humanities worldview of tourism studies that attempts to bring critical and philosophically led approaches to knowledge creation (Platenkamp and Botterill, 2013). The growth in the popularity of discourse analysis, and its increasing recognition as a legitimate research strategy in tourism research is ostensibly a response to an increasingly salient argument that tourism has been historically dominated by a positivist research agenda focussed on business efficiency and management. A more critical tourism research agenda to address particular complexities involved in tourism such as ethics, governance, issues of power, ulterior interests and conflict, and the evolution of tourism research and practices continues to evolve (Fazito et al, 2015). This is an extension of a wider social scientific shift towards discourse analysis. As Trappes-Lomax (2008:134) acknowledge, many areas of academic study have become gripped by an enthusiasm for discourse analysis as a consequence of a "....falling off of intellectual security in what we know and what is means to know..." The authors also observe a growth in linguistic perspectives in the social sciences in analyses of conversations, stories and written texts, particularly since in the service, advertising and communications industries that dominate the economic landscape discourse in not simply a function of work, but is itself, work. Hannam and Knox (2005) offer a useful summary of some approaches to discourse analysis that have been deployed in tourism research to date, albeit with a disproportionate focus on the range of methods that have been applied, at the expense of understanding the complexities of the philosophies that should precede these as considerations in the design of research. These approaches are summarised below: 


\section{INSERT TABLE 1 HERE}

The frequency of structured discourse analytical approaches within the discipline has increased in recent years and this can be confirmed through even the most superficial search of academic databases including Emerald, Science Direct and JSTOR. The increase in popularity of the approach as a research strategy is conceivably linked to the pronounced emergence and continued expansion of digital media sources in tourism over the last decade as social media and image-sharing websites continue to dominate modes of communication (Xiang and Gretzel, 2010). It is important however to acknowledge the sheer variety of types of discourse analysis that are available to the tourism researcher, and to recognise that it is neither possible, nor productive to attempt to review them all. The above snapshot of recent attempts that have been made by tourism scholars to apply discourse analysis to research contexts, whilst useful for drawing distinctions between various approaches (such as semiotics and post-structural analysis) avoids offering any detailed insight into how one might go about 'doing' discourse analysis. The absence of such a practical orientation renders much of the discussion in this, and other summaries and critiques of discourse analysis in tourism research as abstract and not particularly useful for tourism students and early researchers who are seeking to understand how to put research concepts and abstract epistemological ideas into operation. The ensuing discussion therefore attends to this interpretive deficit by exploring Foucauldian discourse analysis, and specifically, the principles in Archaeology of Knowledge in some detail in a way that offers current and future researchers insight into one approach that might be taken to critique tourism contexts as 'systems of formation' (Foucault, 1969).

\subsection{Background to Foucault and uses in Tourism Research}

Foucault's work can be approached based on a range of intellectual and critical standpoints and he has been variously regarded as a philosopher, a social historian, a literary analyst as well as a social/political critic (Gutting, 1989). His collective work can be considered to offer a critique of aspects of Western thought, and he regarded autonomous human thought as an instrument of liberation from structuralism. For example, his treatment of bodies of 
scientific knowledge such as psychiatry sought to expose how such structured 'truths' can in fact serve to constrain and limit the potential of human beings. The relevance to tourism is made clear by Hollinshead (1999) who suggests that Foucauldian analysis could make more visible the sorts of structured truths that tourism stakeholders tend to privilege (and thus constrain and limit) through the 'everyday talk and deeds' of, for example guidebooks, museums and organised tours. Indeed, Foucault's critiques have done much to alter perceptions about the cultural role of philosophy (Gutting, 1989) and they have been used methodologically to question aspects of the self-understanding and thus restrictive and essentialist role of human scientific understanding. Foucauldian thinking is useful to achieve an analysis of the constitution of knowledge and discourse in a particular field, and, as Kendall and Wickham (2009) point out, Foucauldian methods can be productively applied to the identification of a 'problem', rather than a historical period. Relevant therefore is the field of tourism, and the way tourism constitutes, for example 'the destination', through rule-bound discourses, rituals and praxes. This philosophical approach first emerged in the work of Nietzsche, for whom genealogy was a critique of modern morality as a product of power relations (Sarup, 1993). Nietzsche applied his analysis to Christianity and aesthetic morality and distinguished '...a way of life (rather than a 'belief') or 'practice' which is specifically associated with Jesus" (Geuss, 1994: 279). His contention was that Christianity could be said to exist following a set of existing antecedent practices which, as they evolved, were attributed specific interpretations which in turn imposed new meanings on Christianity. The parallels with tourism are clear given that tourism activity is a practice "by which peoples, places and pasts and labelled and classified' (Hollinshead, 1999:10) and are thus repeated and maintained within a discursive regime that is immediately recognisable as tourism. Foucault's elaboration of Nietzsche's genealogy sought to '...desubjugate historical knowledges; to set them free' (Foucault, 2003, cited in Medina, 2011: 12).

Foucault's genealogical and archaeological ideas; his methods for questioning taken for granted beliefs, can be said to liberate a form of counter history by examining experiences and memories that are not given representation in 'official histories' of the type that are encountered by tourists. Chronologically speaking, Foucault introduced archaeological analysis first in his 1969 methodological treatise Archaeology of Knowledge which identified 
the reasoning that he applied in his earlier titles examining institutionalised discursive formations in, for example, madness and medicine (Lord, 2006). The idea behind the archaeological method was that systems of thought (discursive formations) are governed by rules, which transcend grammar and operate subconsciously to define the conceptual boundaries of thought in a given domain or in defined periods of time. The limitation of this approach was that it could reveal very little about the causes of variation from one way of thinking to another. Genealogy, a method first used in Discipline and Punish set out to attend to this limitation by revealing that systems of thought are the consequences of contingent changes in history, rather than inevitable trends (Prado, 2000). In tourism contexts, archaeological analysis involves critiquing discourses and praxes in order to identify which subject positions and objects of discourse are privileged, and which are absent or maintained as eccentric. Subject positioning is usefully defined by Davies and Harre (1990) as the locating of selves in conversation in such a way that what one person says can position another. The concept is similar to the notion of a social role, yet refers to a more fluid idea of multiple identities and the ways in which these are constructed in various discursive contexts. An example from the research that this paper reflects on is the dynamic identities that genocide victims are allocated in museum settings (discussed later). Foucault's aim in terms of archaeological analysis was to examine ontological possibilities (ways of 'knowing') that are against the grain, and which are not compatible with the available and legitimated historical narratives of a given time. The goal of genealogy is therefore to affect a vibrant pluralism by tracing the discursive formations that authorise particular forms of knowledge and power. A number of genealogical critiques of tourism contexts have been developed (see for example Hooper-Greenhill's, (1989) critique of museums, and Simpson's (2015) study of tourist utopias), yet attempts to deploy the concept to empirical research are hard to come by.

The idea of power is central to Foucault's life study of topics, which include madness, punishment and human sexuality, and he maintained that 'power is so inextricably wedded to knowledge that one cannot be analytically considered without the other' (Cheong and Miller, 2000:375). One of the more popularised concepts to arise out of Foucault's work as it relates to tourism is the idea of the 'gaze', first brought into focus in a tourism context by Urry (1990). The concept of the gaze originates from the idea of Bentham's Panopticon; a 
prison designed in a way that gives the overseer at the centre the ability to see everything, and everyone at any time without the knowledge of those being observed. Ultimately the observed come to internalise the gaze to the extent that he becomes his own overseer (Foucault, 1997, cited in Cheong and Miller, 1990). The praxis of tourism has been compared to the 'parental gaze' in the sense that, as tourists we are compelled to learn to see and exhibit a particular kind of 'normal' (touristic) behaviour which confines us to a particular way of seeing and knowing. It is difficult, however to find examples of this, and other interpretations of Foucault's work deployed within tourism research strategies. Hollinshead (1999) catalogues the ways in which Foucauldian thinking has been, and could be used as a central philosophy within tourism research contexts. These include critiques of power relations and what is privileged as 'truth' through tourism, analyses of the representations of tourism, the commoditisation of narratives of history, and the essentialist ways in which objects of knowledge in tourism come to be known as inevitable or natural. Again, there are no examples amongst these suggestions of primary research strategies that are based on Foucauldian ideas that can be drawn upon and adapted in future tourism research. This is perhaps a consequence of the absence of coherent descriptions of how to go about doing discourse analysis based on Foucault's thinking, conceivably because such descriptions are taboo. This idea, and the suggestion that there is some reluctance amongst researchers to declare method for fear of appearing descriptive is discussed below as a preamble to a proposed Foucauldian discursive analytic that can be applied to tourism studies.

\subsection{Fear of Foucault, and Archaeology of Knowledge as Methodology}

Archaeology of Knowledge represents Foucault's only attempt to offer a methodological reflection over his life work, and it is within this body of work that he suggests that a search for 'truth' within culture and the sciences is futile. What is much more important is to understand how objects of truth might come to be formed in ways that limit and restrict how discourses come to be known, accepted and maintained (Graham, 2005). Foucault's methodological premise is that archaeological analyses can serve to critique 'statements' (things said which privilege certain ways of seeing and cataloguing discursive practices) to identify the discursive frame which forms around particular constructions of 'truth'. It is the 
regularity of statements, their material repeatability, which can come to be understood by the researcher as a discursive formation (ideas that are elaborated upon in the section below). However, many scholars have been left frustrated by the challenge of how to adopt these methodological ideas within a methodology given that the texts they access are often 'too difficult to penetrate' (Ibid: iX) and there is, as Fadyl et al (2013) note an overwhelming agenda of possible approaches to carrying out discourse analysis that follows Foucault. This paper was motivated by these very kinds of frustrations and the challenges and dilemmas experienced in having to develop a clear methodological itinerary to carry out discourse analysis on museums and sites of memory across Lithuania between 2006 and 2011. The aim is not to replay the findings of this research (see Wight, 2016 for an elaborated account), but to reflect on the challenges encountered when developing a suitable methodological approach in order to leave behind a clearly identifiable trail for other tourism researchers who are drawn to discourse analysis as a research methodology and to Foucault as an adjunct research philosophy.

The aim of the research context that is the subject of reflection here was to critique museums and sites of memory as spaces in which competing discourses of cultural identity emerge to explore how heritage sites as discursive tourism texts play a role in maintaining the cultural identity of Lithuania. The research was motivated by the ostensibly troublesome place of 'genocide' within the public culture of a nation with a complex recent past involving occupation and annexation at the hands of the Soviets and Nazi Germany. The research process involved multiple visits to, and analysis of several Lithuanian genocide themed heritage sites in order to critique their narrative content, which comprised of hundreds of photographs, exhibitions, visitor interpretation and artefacts which had to be catalogued, consulted and subjected to analysis. The type of tourism that was the focus of analysis here is widely acknowledged as 'dark tourism', and is also arguably an example of what Korstanje $(2012,2018)$ describes as an emergent class of 'death seeker' tourists, motivated by the opportunity to experience and understand death related narratives through tourism encounters. The challenge in creating a suitable methodology was to achieve what Graham (2005:2) refers to as the need to "engage with the awkward tension that arises when one attempts to do post-structural work whilst still satisfying the conventions of academic writing and scholarship". What became clear quite quickly into the research process was the 
inherent difficulty in identifying coherent descriptions of how to proceed with discourse analysis based on Foucauldian thinking. Authors such as Cheong and Miller (2000) and Fadyl et al (2013) acknowledge a perceived fear that in claiming to be drawing on a Foucauldian framework, there is a risk that one's ideas might be dismissed as 'un-Foucauldian'. Such a dilemma is behind the reason that a Foucauldian approach to discourse analysis is seen as inaccessible and perilous (O' Farrell, 2005, cited in Graham, 2005) and therefore unattractive as a methodological option. A major obstacle to adopting Foucault is the widely acknowledged problem that he was against any form of global theorising (Sarup, 1993) and any totalising approach to analysis and systemisation. Although this point perhaps appears somewhat protectionist, it is unlikely that Foucault would have wished to have remained inaccessible to future generations of academics. Nonetheless, researcher reluctance is unsurprising given that Foucault's life work was produced based on the central assertion that history cannot be viewed as a seamless evolution of knowledge that can be ordered and categorised.

The dominant perception of Foucault's work is that he was fundamentally concerned with examining disorder and 'ruptures' in societal knowledge and the way in which he achieved this was to examine 'the document' as a product of powerful societal actors who choose which fragments of history could be left behind in the advancing of knowledge. When one is confronted, therefore, with the task of identifying a methodology to conduct tourism research based on discourse analysis, a number of challenges emerge. For a start, tourism discourse analysis need not be concerned with people, since the core unit of analysis is invariably 'text' and other non-discursive domains such as institutions (for example attractions or museums) and 'events' (such as tourism strategies, political change and marketing campaigns); which of course does not explicitly discount the capturing and analysis of snapshots of the spoken word, but which can explicitly be based upon analyses of rigorously conceptualised texts (for example guidebooks or web content) and broadcast media (such as web 2.0 and social media). It is Jacques Derrida who is credited with first redefining the boundaries of the text. Di Pietro (1976) captures the Derridean poststructuralist approach to the text in noting that the property of 'being a text' is assigned by the reader, and so the text does not constitute an inherent property. Texts, in the context of tourism can include any space in which objects of discourse (discrete 'truths' about 
destinations and their actors) are produced. Foucault's Archaeology of Knowledge can be viewed as productive conceptual lens to deliver a critique of such texts.

\section{3 'Doing' Foucauldian Discourse Analysis in Tourism: A Discursive Analytic}

Despite the acknowledgement that Archaeology of Knowledge was not intended as a methodological prescription, it has nonetheless proved useful in analysing discourse, particularly where the underlying research philosophy embraces structuralist and social constructivist reasoning (Andersen, 2004). Amongst the commonalities that exist between most published studies that have harnessed archaeological discourse are the following key concepts (Ibid: 8)

- The statement which can be considered to be the smallest unit of discourse. Foucault is elusive about a definition, but studies tend to approach the statement as a meaning that follows the 'agreed codes' (Foucault, 1969:104) of a broader discourse. To identify a discourse, those involved in its production must be 'talking about 'the same thing', by placing themselves at 'the same level' or at 'the same distance', by deploying 'the same conceptual field"' (Ibid: 126). However, Andersen (2004) points out that statements are, themselves, the product of discourse analysis. As such, it is the discourse analyst that defines statements through discourse analysis. The analyst 'constructs the regularity of the dispersion that is the discursive formation' (Ibid: 8). The statement, and the rules of its formation are proposed by discourse analysis.

- Discourse which is the total articulated body of formulated statements and this is also referred to as the 'archive' in archaeological discourse analysis

- The Discursive formation which is a system of dispersion for statements. The 'rules of formation' describe the regularity in these statements.

A key concept in Foucauldian methodological thinking is this latter idea of 'discursive formation'. A discursive formation can be viewed as a body of anonymous, historical rules and statements which emerge in the time and space of a given period; what Foucault terms an episteme. To identify a discursive formation in the context of tourism research is to contextualise the unit of analysis and its discursive practices as 'enunciations' (Foucault, 
1969). In the case of the research that motivated this reflective paper, the units of analysis were museums and sites of memory and their enunciations were instructive texts, such as written and spoken visitor interpretation and visitor guidebooks. A useful metaphor for understanding discursive formation which was encountered during the course of undertaking research into museums and sites of memories came from Radford et al (2002). To understand the concept, they suggest, one must imagine oneself standing in a library facing a collection of books arranged on the shelves. They are arranged in a specific format, usually according to the proximity of their subject matters. Attempting to understand why they are arranged in this particular way is similar to attempting to understand a discursive formation since they are arranged in a particular order, according to the judgement of 'qualified' people who possess the legitimate levels of authority to be able to authorise the arrangement. There is something beyond the books themselves that enables the 'expert' to arrange the titles in certain ways and this enables '...rules for the repeatability of statements' (Kendall and Wickham, 2009:27). The analogy resonates with Foucault's (1969: 38) definition of the concept in stating: 'whenever between objects, types of statement, concepts or thematic choices, one can define a regularity (an order) we will say, for the sake of convenience, that we are dealing with a discursive formation'.

Any authoritative tourism text can be approached based on such an epistemological strategy in the sense that narratives such as guided tours, destination guide resources and web content to offer some examples are deployed and arranged in a particular order according to the legitimated preferences of their authors, who also make decisions about which narratives should not be deployed. In this way, tourism narratives can be viewed as objects of discourse that are classified according to the frameworks of knowledge that allow them to be understood. Such narratives occur as dispersed statements that are nonetheless part of a rule bound discursive formation constituting a 'body of knowledge' that authorises certain discourses at the expense of others.

The concepts and terminologies that appear in Archaeology which are central to the pursuit of a discursive formation are given some interpretation in the context of tourism studies in the table below. The purpose of the table is not to appropriate these terminologies into a finite or deterministic framework, but rather to offer a contextualised interpretation of the 
key concepts in archaeology in such a way as to create more access to them for researchers who are approaching tourism contexts as discursive practices. It would be impossible to list all potential tourism research contexts in which Foucauldian methods could be productive in this, or any body of work, and so the table below is provided to begin a conversation by suggesting some ways in which Foucault could be understood. The table is arranged in such a way as to reflect on how the concepts were interpreted within the study of museums and heritage sites that this paper was motivated by, and how they might be interpreted more broadly in other studies of tourism.

\section{INSERT TABLE 2 HERE}

The above synthesis can be approached as an invitation to an interpretive framework for Archaeology of Knowledge. It is intended as a contextualised analytical lens to understand tourism discourses based on an elaborated reflection on its application to a specific primary research context, and to possible notional tourism contexts. Discourse analysis of any type offers a way of thinking about a particular research problem, rather than a catch-all method since there is no obvious parallel to controlled experimental design and prescriptive tests of statistical significance (Potter and Wetherell, 1987:). It should be approached, not as deterministic or as a means to 'oversimplify the subtle nuances in Foucault's approach' (Nicholls, 2005: 39) but as an interpretation that remains true to the approach whilst being clear about how it might be applied to a range of tourism research contexts. Whilst it leaves the tourism researcher with work to do (the horizon of possibilities for its application to tourism research cannot possibly be captured in a simplistic way), it offers a way of understanding and deploying the key concepts associated with archaeological discourse analysis to studies of tourism, and in this way it can be useful in both pedagogical and research tourism settings. It enables the researcher to conceptualise and study tourism as a discursive practice that constitutes, within a range of cocooned discursive settings various discrete forms of knowledge or regimes of truth. Carrying out archaeological discourse analysis necessitates a focus on identifying and describing the body of anonymous rules (Foucault, 1969) that constitute tourism as a discursive practice. In the context of the study of museums and sites of memories identified above, this involved identifying and describing the regularity with which ideas and 'truths' about objects of discourse are produced, often 
from the perspective of privileged subject positions. Foucauldian analysis, in this sense is a critique of the taken for granted forms of 'truth' that emerge through tourism narratives. Developing these ideas within a completed research strategy requires some consideration of an appropriate research technique, specifically, and in terms of tourism studies.

\subsection{A Technique for Applying Foucault in Tourism Research}

An elaborated version of the methods and findings that were undertaken towards the completion of the Lithuanian heritage analysis upon which this methodological reflection is based can be accessed elsewhere (see Wight 2016). What is more important given the immediate purpose of this paper is to offer some practical advice to tourism researchers who have chosen to apply Foucauldian reasoning within their research. The discursive analytic that was developed to apply the above concepts within the study of Lithuanian heritage sites that this paper follows was informed by the key methodological propositions advanced by Nicholls (2009) who proposed a set of principles that can be instructive in carrying out Foucauldian discourse analysis. The first of these propositions is to engage with a 'plurality of texts' requiring patience, attention to detail and an accumulation of source materials. Forms of data may include any source that can critiqued for meaning including language, text, images, events and objects (Morgan, 2010). In terms of applying this thinking to a critique of heritage as discursive formation, all of the high profile (popularly visited) heritage sites that articulate narratives of 'Lithuanian at war' were visited and experienced in as autonomous sites of articulation. In this sense, and in broader tourism research contexts, the aim is to map the terrain upon which knowledge is formulated. Foucault used a geological metaphor to explain how to approach knowledge suggesting that discourse analysis is about excavating beneath the surface of discourses by considering a wide range of texts spread over a broad horizon based on a range of source materials. It is here that consideration must be given to a suitable choice of materials, and this is entirely dependent upon the research problem (Table 2 presents some possibilities).

The second of Nicholls' propositions is to focus on 'local, material practices' (2008:37). Here he cautions the researcher away from seeking the effects of discourses in 'grand theories and ideologies' and suggests exploring texts 'in the locations where oppression, forms of discipline, regulations and constraints, binaries of separation, claims of originality, and self 
evident truths are present' (Ibid: 37). He suggests therefore focusing on the immediacy of events in the conduct of the practices that are being analysed. An analysis of a complete discursive field is unrealistic so the units of analysis and the research strategy must be limited but clearly designated. The study of heritage that this paper stems from was therefore restricted to museums and sites of memory approached as surfaces of emergence which play a role in the broader discursive production of the destination identity of Lithuania. Again, the speculative tourism discourse analyst must contemplate a suitable choice of material which will depend on the research question, knowledge of appropriate sources, and the availability of appropriate sources (Jorgensen and Philips (2002). Nicholls further suggests the researcher should 'seek out places where material practices are inscribed, documented or stated, and focus on practices that seem obvious or taken for granted' (2008: 38). Museums offer one such field of analysis within a study of heritage, whilst in other tourism research contexts the choice of materials will be led by the research context. Finally, Nicholls counsels that one should attend to the 'ruptures, fissures and tensions' on the surface of discourses and instead of seeking out thematic continuities that only serve to reinforce the progressive outlook of history, we should explore new discursive forms by 'problematising tensions, fissures and ruptures that might otherwise appear to be continuous discourses' (2008: 38).

In terms of putting this analytical ethos into operation, the 'texts' that were analysed in the study of heritage that this paper follows were the museums themselves, and as spaces of discourse production they were conceptualised as discursive practices that circulate and disperse discourse. In addition to analysing the museums themselves, other textual resources were collected since these were considered to be instrumental components within the discursive practice of the museums. Visits to, and analysis of these sites and the ancillary texts that were collected took place during a 5 year phases of data collection. In terms of a strategy for fieldwork, several hundred photographs of exhibitions, visitor interpretation and other artefacts were taken, and maintained in digital format, and a wide range of ancillary texts were collected and analysed. In undertaking this form of discourse analysis, a systematic approach might focus on discovering "how; under what conditions, and for what reasons discourses are constructed, contested and changed" (Howarth, 200, cited in Letts, 2009). A case study approach was therefore considered an appropriate way to 
'locate the articulatory practices' (Ibid) of the museums and sites of memory that were the subject of analysis and a form of content analysis was undertaken to identify themes, although no prescriptive approach was followed. Such an approach is not essential for achieving the aims of tourism research considered more broadly. Indeed, it would be counterproductive to suggest that these research choices in relation to methods are appropriate for all tourism research contexts. In coming up with a bespoke discursive analytic it is useful to consider that discourse analysis is not simply a 'method', but an holistic approach. Any of the methods described in Table 1 could be deployed in order to make sense of data and some thought must be given to the availability and nature of source materials. Whatever approach is taken, it is the necessity to develop an accumulation of familiarity with source materials that is probably the principal 'constant' to Foucauldian discourse analysis. Finally, the very practice of discourse analysis necessitates its own central weakness, which is that analysis is unavoidably based to some degree on subjective observations and interpretations of phenomena, as opposed to following one of the more typically prescriptive research strategies offered via interpretive and positivist routes to knowledge creation (Yin, 2010). This and other limits to deploying the discursive analytic presented above are discussed below.

\subsection{The Limits of Foucauldian Discourse Analysis}

Since no claims are made to revealing the legitimacy of discourses (assertions which come as close as they can to revealing a 'truth') identified through discourse analysis, a key limitation of the approach is that competing claims to alternative discourses that might be identified by another researcher examining the same cultural phenomenon are always possible (Powers, 2001). Such a limitation is not however the unique preserve of discourse analysis since the refutation of findings is a common occurrence in all social-scientific research. In addition, the results of Foucauldian discourse analysis can never be 'generalised' to other situations, other discourses, or other communities or individuals (Ibid: 64). The hunches or hypotheses that are made about discourse must be tested using an appropriate analytical method. Powers (Ibid: 64 ) also suggests that discourse analysts tend to anticipate that their work might 'raise the consciousness' of both the reader and of the stakeholders practising within the context of the discourse that is analysed, in many cases to '...reduce oppression and provide alternate speaking positions'. Simply put, there may be a 
poetical or cultural agenda underpinning the analysis undertaken (Wight, 2016). One of the dangers suggested by this limitation is that resistant discourses can become co-opted, or remain unseen by those for whom the analysis is intended. It is almost certainly a challenge for anyone that attempts to analyse discourse to remain impartial as a subject, and to deny the existence of 'truth' in the manner that is requested by Foucault. Discourse analysts also receive criticism for portraying a world that exists independent of the language that constructs it. However, as O' Donnell and Spires (2012:19) reflect '...not all, of course is discourse', and visits to museums as well as encounters with other cultural commodities can be seen purely as inconsequential and fun forms of entertainment.

In terms of the ethics of discourse analysis, the key debates reside in how knowledge is produced and in how to locate the findings between the two poles of advocacy (the manufacturing of option) and objective reflection. As Wrbouschek (2009:41) puts it, if discourse, as identified through research, is understood as a kind of truth articulation then in 'pointing to these facts' the researcher effectively situates himself inside an act of truth constitution which is itself contingent on discursive origins. The 'risk' therefore in carrying out discourse analysis is constructing and advocating 'truth', rather than offering an understanding of how power constitutes discourse, knowledge and subjectivities in a given phenomenon such as tourism. As Jorgensen and Phillips, (2002:15) put it 'because truth is unattainable, it is fruitless to ask whether something is true or false. Instead, the focus should be on how effects of truth are created in discourses'. If there is a practical adherence to a code of 'researcher ethics' in terms of Foucauldian discourse analysis it is in forming conclusions that are acknowledged as being limited to the analytical method out of which they arise. 


\section{Conclusion}

The aim of this paper was to offer an interpretation of Foucault's methodological reasoning based on a reflection over primary research undertaken into heritage sites as examples of tourism destination discourses. By offering a contextualised synthesis of the epistemological reasoning set out in Archaeology of Knowledge the paper offers tourism researchers who view discourse analysis and post-structuralism as productive methodological strategies an orientation to a proposed conceptual lens to apply to a range of tourism research contexts. The discursive analytic that is produced contributes towards a counterbalance movement within tourism research culture that sees the discipline increasingly approached using critical reasoning, as opposed to replaying the more familiar methodological approaches that maintain the discipline as a technically rational, principally economic phenomenon (Tribe, 2008). The paper elaborates upon the idea of discursive formation to develop an understanding of tourism spaces as discursive regimes which have a hand in the authorship of social identity. The discursive analytic presented is based on a dialectic approach to Foucauldian research since it takes orientation from earlier examples of 'applied Foucault' including Radford et al's (2011) study of de-accessioned books in libraries, Graham's (2005) reflection over deploying Foucault-as-method and O'Donnell and Spire's (2012) study of the televised Super Bowl. The interpretation that is produced is not a 'finished product'. Rather it is intended to help researchers to identify with a way of thinking about Foucault's methodological ideas when confronting various tourism research settings and problems.

The paper makes four key points as follows:

- Discourse analysis of the type discussed here can be a useful research strategy to apply to tourism research contexts. As a methodology it can be helpful to researchers and to stakeholders involved with the management and planning of tourism, particularly when it comes to areas such as visitor interpretation and the authoring of authoritative tourism narratives and texts. Where the researcher is able to accumulate familiarity with a well-defined surface of emergence there exists an 
opportunity to critique through primary research the ordering of knowledge and the role of power in tourism settings.

- Whilst there has been some usage of Foucault in the literature relating to tourism, it is rare to find any examples of Foucauldian 'method' anywhere in the literature, possibly because of Graham's (2005) observation about the reluctance of scholars reading Foucault to 'declare method'. This paper suggests that it is possible, and indeed necessary to articulate how one intends to go about doing Foucauldian discourse analysis in tourism research without over simplifying interpretations of his work. The discussion should be approached as a contribution to a methodological debate, rather than as a panacea for applying Foucault.

- Tourism comprises of a range of sites and spaces of cultural hegemony, and for the researcher this represents fertile ground for the application of a discursive analytic. This paper has identified and interpreted one such discursive analytic based on a reflection over its use in recent research, and it has set out how future tourism researchers might plan and undertake research using this approach.

- There are a number of methodological limitations that should be acknowledged when considering a Foucauldian approach to discourse analysis. Specifically, discourse analysts tend to receive criticism for portraying a world that exists independent of the language that constructs it, and it is always difficult to avoid any attempt to reveal the 'legitimacy' of discourse in the course of carrying out what is unavoidably a subjective approach to knowledge creation.

The paper therefore attends to a conceptual deficit by offering a reading of a post structuralist, Foucauldian discursive analytic to understand heritage and tourism experiences as texts. Using this approach, tourism can be critiqued as a set of discursive practices which articulate and disperse meaning. Discourse analysis is a way to critically approach tourism narratives for a range of purposes and agendas. These include societal pressures to offer balanced accounts of histories, people and places and a growing necessity for heritage sites in particular to offer inclusive experiences. 


\section{References:}

Anderson, J. (2004). Talking Whilst Walking: A Geographical Archaeology of Knowledge. Area, 36 (3), 254-61

Berdychevsky, L., Gibson, H., \& Bell, H. (2016). "Girlfriend Getaway" as a Contested Term: Discourse Analysis. Tourism Management, 55, 106-122

Bhattacharyya, D. (1997). Mediating India: An Analysis of a Guidebook. Annals of Tourism Research, 24 (2), 371-389

Cheong, S., \& Miller, M, L. (2000). Power and Tourism: A Foucauldian Observation. Annals of Tourism Research, 27 (2), 371-390

Coles, T., \& Timothy, D, J. (2004). Tourism, Diasporas and Space. London and New York: Taylor and Francis

Davies B., and Harre, R. (1990). Positioning: The Discursive Production of Selves. Journal for the Theory of Social Behaviour. 20 (1) 43-63

Di Pietro, R. (1976). The Strategies of Language Use. In P, A. Reich (Ed.), The Second LACUS Forum, 1975. Colombia: Hornheam Press.

Dowling. R., \& Cowan, E. (2017). Cruise Ship Tourism (2 ${ }^{\text {nd }}$ ed.). London: CABI

Fadyl, J, K., Nicholls, D, A., \& McPherson, K, M. (2013). Interrogating Discourse: The Application of Foucault's Methodological Discussion to Specific Enquiry. Health: An Interdisciplinary Journal for the Social Study of Health, IIIness and Medicine, 17 (5), 491-507

Fairclough, N. (1992). Discourse and Social Change. Cambridge: Polity Press

Fazito, M., Scott, M., \& Russell, P. (2016). The Dynamics of Tourism Discourses and Policy in Brazil. Annals of Tourism Research, 57, 1-17 
Foucault, M. (1969). The Archaeology of Knowledge. London: Tavistock

Frew, E and White, L. (2013). Exploring Dark Tourism and Place Identity, in White and Frew (Eds) Dark Tourism and Place Identity. Routledge

Geuss, R. (1994). Nietzsche and Genealogy. European Journal of Philosophy, 2, 275-292

Graham, L, J. (2005). Schooling and 'Disorderly' Objects: Doing Discourse Analysis using Foucault. Presented at the Australian Association for Research in Education 2005 Annual Conference, Sydney $27^{\text {th }}$ November $-1^{\text {st }}$ December

Grenz, S, J. (1996). A Primer on Postmodernism. Michigan: Wm. B Ebermans Publishing Co.

Guedes, A, S., \& Jimenez, I, M. (2016). Conceptualizing Portugal as a Tourist Destination through the Textual Content of Travel Brochures. Tourism Management Perspectives, 20, 181-194

Guidotti-Hernandez, N, M. (2011) Unspeakable Violence: Remapping US and Mexican National Imaginaries. Duke University Press. Durham

Gutting, G. (1989). Michel Foucault's Archaeology of Scientific Reason: Science and the History of Reason. Cambridge University Press

Halewood, C., \& Hannam, K. (2001). Viking Heritage Tourism: Authenticity and Commodification. Annals of Tourism Research, 28, 565- 580.

Hall, S. (1997). The Work of Representation. In S. Hall (ed.) Representation: Cultural Representations and Signifying Practices. London: Sage.

Hannam, K., \& Knox, D. (2005). Discourse Analysis in Tourism Research: A Critical Perspective. Tourism Recreation Research, 30 (2), 23-30 
Hollinshead, K. (1999). Surveillance of the Worlds of Tourism: Foucault and the Eye-of Power. Tourism Management, 20, 7-23

Hooper-Greenhill, E. (1989). The Museum in the disciplinary Society. In S, M. Pearce (ed.) Museum Studies in Material Culture. Leicester University Press

Johnstone, B. (2008). Discourse Analysis. Malden, USA: Blackwell Publishing

Jorgensen, M, W., \& Phillips, L. J. (2002). Discourse Analysis as Theory and Method. London: Sage

Kendall, G., and Wickham, G (2009). Using Foucault's Methods. London. Sage Korstanje, M. E (2012). Reconsidering cultural tourism: an anthropologist's perspective. Journal of Heritage Tourism, 7(2), 179-184.

Korstanje, M, E. (2012). Tourism and Terrorism. Conflicts and Commonalities. Worldwide Hospitality and Tourism Themes. 4. 1. 8-25

Korstanje, M, E. (2018). The Rise of Thana-Capitalism and Tourism. Routledge Letts, M. (2009). Obama's Discourse of 'Hope': Making Rhetoric Work Politically. School of Sociology, Politics and International Studies. Retrieved May $29^{\text {th }}, 2017$, from http://www.bristol.ac.uk/spais/research/workingpapers/wpspaisfiles/letts0409.pdf

Lord, B. (2006) 'Philosophy and the Museum: An Introduction to the Special Issue'. Museum Management and Curatorship, 21, pp79-87

Medina, J. (2011). Towards a Foucauldian Epistemology of Residence: Counter-Memory, Epistemic Friction, and Guerrilla Pluralism. Foucault Studies, 12, 9-35 
Morgan, A. (2010) Discourse Analysis: An Overview for the Neophyte Researcher. Journal of Health and Social Care Improvement, 1, 1-7

Nicholls, D, A. (2009). Putting Foucault to work: An Approach to the Practical Application of Foucault's Methodological Imperatives. Aporia, 1 (1), 30-40.

O’Donnell, H., \& Spires, B. (2012). America at Play, America at War: the Super Bowl as Discursive Formation, in Comunicação Pública, 6, 43-72.

Paltridge, B. (2006). Discourse Analysis: An Introduction. Continuum

Platenkamp, V., and Botterill, D. (2013) Critical Realism, Rationality and Tourism Knowledge. Annals of Tourism Research, 41, 110-129

Potter, J., \& Wetherell, M. (1987). Discourse and Social Psychology: Beyond Attitudes and Behaviour. London: Sage

Powers, P. (2001). The Methodology of Discourse Analysis. Jones and Bartlett Publishers Inc. Prado, C, G. (2000) Starting with Foucault: An Introduction to Genealogy. Routledge, New York

Sarup, M. (1993). An Introductory Guide to Post Structuralism and Post Modernism. New York: Harvester Wheatsheaf

Simpson, T. (2015). Tourist Utopias: Biopolitics and Genealogy of the Post-World Tourist City. Current Issues in Tourism, 16 (1), 27-59

Titscher, S., Meyer, M., Wodak., R., and Vetter, E. (2000). Methods of Text and Discourse Analysis. London: Sage

Trappes-Lomax, H. (2008) Discourse Analysis. In A. Davies and C. Elder (eds.) The Handbook of Applied Linguistics. Blackwell Publishing 
Tribe, J. (2005). New Tourism Research. Tourism Recreation Research, Vol. 30 (2) pp. 5-8

Tribe, J. (2008). Tourism: A Critical Business. Journal of Travel Research, 46 (3), 245-255

Tzanelli, R. (2017) Schematising Hospitality: Ai WeiWei's Activist Artwork as a Form of Dark Travel. Mobilities. 13 (4) 520-534

Urry, J. (1990). The Tourist Gaze: Leisure and Travel in Contemporary Societies. London: Sage

Uzzell, D. (1984). An Alternative Structuralist Approach to the Psychology of Tourism Marketing. Annals of Tourism Research, 11, 79-99.

Van Dijk, T, A. (1993). Principles of Critical Discourse Analysis. Discourse and Society, 4 (2), 249-283

Wight, A, C. (2016). Lithuanian Genocide Heritage as Discursive Formation. Annals of Tourism Research, 59, 60-78

Wilkes, K. (2016). Whiteness, Weddings and Tourism in the Caribbean: Paradise for Sale. Palgrave MacMillan

Xiang, Z., \& Gretzel, U. (2010). Role of Social Media in Online Travel Information Search. Tourism Management, 31 (2), 179-188 
Table 1: Types and Examples of Discourse Analysis in Tourism Research (adopted from Hannam and Knox, 2005)

\begin{tabular}{|c|c|c|}
\hline $\begin{array}{l}\text { Discourse Analysis } \\
\text { Approach/Method }\end{array}$ & $\begin{array}{l}\text { How this method might be } \\
\text { applied }\end{array}$ & Examples from the literature \\
\hline Content analysis & $\begin{array}{l}\text { Counting and interpreting the } \\
\text { content of texts to identify what is } \\
\text { significant. For example, examining } \\
\text { brochures over time to illuminate } \\
\text { permanencies and variations in the } \\
\text { representation of people and } \\
\text { places }\end{array}$ & $\begin{array}{l}\text { Bhattacharyya's (1997) coding of } \\
\text { photographs in the Lonely Planet } \\
\text { to categorise these into broad } \\
\text { typologies and to identify how } \\
\text { 'people' are represented. }\end{array}$ \\
\hline Textual analysis & $\begin{array}{l}\text { A qualitative technique concerned } \\
\text { with interpreting cultural meaning } \\
\text { from texts. Less standardised than } \\
\text { content analysis and underpinned } \\
\text { by the idea that texts are complex } \\
\text { sites of social construction. } \\
\text { Themes can be created based on } \\
\text { coding. }\end{array}$ & $\begin{array}{l}\text { Halewood and Hannam's (2001) } \\
\text { analytical framework to identify } \\
\text { discrete references to authenticity } \\
\text { in heritage tourism sources. }\end{array}$ \\
\hline Semiotic Analysis & $\begin{array}{l}\text { Concerned with the production } \\
\text { and consumption of images, for } \\
\text { example images within brochures } \\
\text { or as part of web content. } \\
\text { Examines the complex relationship } \\
\text { between objects and } \\
\text { representation. Can be used to } \\
\text { analyse photographs, postcards } \\
\text { and souvenirs. Less structured } \\
\text { than the above and allows } \\
\text { considerable analytical freedom } \\
\text { and creativity in terms of how } \\
\text { research is undertaken. }\end{array}$ & $\begin{array}{l}\text { Uzzell's (1984) analysis of tourism } \\
\text { brochures points out that } \\
\text { photographs of wine represent the } \\
\text { myth of a good life and symbolize } \\
\text { a degree of freedom from } \\
\text { everyday working life though the } \\
\text { loss of inhibitions. (Hannam and } \\
\text { Knox, 2005: 26) }\end{array}$ \\
\hline Deconstruction & $\begin{array}{l}\text { A Derridean approach to texts } \\
\text { which suggests that discourse is } \\
\text { the outcome of a series of, } \\
\text { sometimes incoherent structures } \\
\text { and utterances that are in conflict }\end{array}$ & $\begin{array}{l}\text { Edensor (1997, cited in Hammam } \\
\text { and Knox, 2005) discusses the } \\
\text { reception of the film Braveheart in } \\
\text { Scotland in the 1990s, pointing to } \\
\text { conflicts surrounding the }\end{array}$ \\
\hline
\end{tabular}




\begin{tabular}{|l|l|l|}
\hline & $\begin{array}{l}\text { with one another. Enables a } \\
\text { nuanced reading to approach texts } \\
\text { within the wider cultural } \\
\text { conditions in which they were } \\
\text { produced. Useful in critiques of } \\
\text { heritage tourism, which are often } \\
\text { socially and culturally contested. }\end{array}$ & $\begin{array}{l}\text { authenticity of this media, but also } \\
\text { the popular surge in nationalism might } \\
\text { be put as a consequence. }\end{array}$ \\
\hline
\end{tabular}


Table 2: Foucault's Archaeology of Knowledge as Discursive Analytic in Studies of Tourism (adapted from Foucault, 1969)

\begin{tabular}{|c|c|c|c|}
\hline $\begin{array}{l}\text { Concept from Archaeology of } \\
\text { Knowledge }\end{array}$ & Broad definition & $\begin{array}{l}\text { Application to Museums and Sites of } \\
\text { Memory (Wight, 2006) }\end{array}$ & $\begin{array}{l}\text { Potential interpretation within a wider } \\
\text { discussion of tourism research }\end{array}$ \\
\hline The statement & $\begin{array}{l}\text { The smallest 'unit' of discourse; albeit an } \\
\text { unstable unit. It is defined according to } \\
\text { its field of use in discourse analysis. The } \\
\text { statement is produced and described in } \\
\text { the process of discourse analysis. } \\
\text { O'Donnell and Spires (2012) identified } \\
\text { 'community' and 'competition' (amongst } \\
\text { others) as statements in the field of the } \\
\text { televised Super Bowl. These emerge on } \\
\text { 'surfaces' such as game commentary } \\
\text { and advertisements. Discourse can be } \\
\text { understood as the plural of the } \\
\text { statement. }\end{array}$ & $\begin{array}{l}\text { The museum is a statement of discourse } \\
\text { and it can also be analysed as an } \\
\text { autonomous discourse comprising of } \\
\text { statements. The museum } \\
\text { conceptualised at the level of the } \\
\text { statement can be identified as a visual } \\
\text { apparatus of signs and symbols (for } \\
\text { example written and visual visitor } \\
\text { interpretation, and the arrangement of } \\
\text { objects, sometimes called 'proxemics' by } \\
\text { exhibitioners) to which a status of } \\
\text { knowledge is ascribed. The statement is } \\
\text { governed by 'rules'. For example, there } \\
\text { are an inherent set of rules governing } \\
\text { the ways in which genocide can and } \\
\text { cannot be spoken about in Lithuanian } \\
\text { genocide museums. These rules only } \\
\text { become obvious following an } \\
\text { accumulation of familiarity with their } \\
\text { surfaces of emergence. Statements may }\end{array}$ & $\begin{array}{l}\text { The context of the research dictates } \\
\text { what the statement will be. Since } \\
\text { discourse is a 'group of statements' } \\
\text { (Hall, 1997) that provides a language for } \\
\text { talking about, or representing a } \\
\text { particular topic at a given moment, } \\
\text { familiarity with the research context will } \\
\text { reveal 'sayable' statements that } \\
\text { constitute discourse. Some examples of } \\
\text { statements that might be encountered } \\
\text { in tourism research include } \\
\text { 'sustainability' in tourism management } \\
\text { discourses, or destination images that } \\
\text { are constructed through marketing } \\
\text { materials of various types. It is the rules } \\
\text { (what is 'sayable') that give these } \\
\text { statements meaning and that ultimately } \\
\text { legitimate what counts as knowledge } \\
\text { within their field of use. To develop } \\
\text { upon the sustainability example, the }\end{array}$ \\
\hline
\end{tabular}




\begin{tabular}{|c|c|c|c|}
\hline & & $\begin{array}{l}\text { be repeated, but their materiality (their } \\
\text { nature and the rules of their formation) } \\
\text { in exhibitory environments varies. They } \\
\text { nonetheless refer to the same object of } \\
\text { discourse (for example the discursive } \\
\text { production of women during conflict, or } \\
\text { of the technology of warfare in the field } \\
\text { of battlefield museum discourse). } \\
\text { Finding regularity amongst the } \\
\text { irregularity of statements is the purpose } \\
\text { of archaeological discourse analysis. }\end{array}$ & $\begin{array}{l}\text { rarefied uses of the term 'sustainability' } \\
\text { in tourism policy documentation could } \\
\text { be critiqued using content analysis to } \\
\text { understand 'the bounds of the sayable' } \\
\text { within this particular context (Tribe, } \\
\text { 2008). The term sustainability would be } \\
\text { subject to particular 'rules' of use that } \\
\text { would select and maintain limits as to its } \\
\text { understanding in such a context. Air } \\
\text { travel can be 'sustainable' in a number } \\
\text { of discursive contexts! } \\
\text { A further example might be the } \\
\text { construction of competing 'expert' } \\
\text { tourism knowledge claims in popular } \\
\text { travel guide books. The rules that govern } \\
\text { how destinations can come to be known } \\
\text { would give form to the statements that } \\
\text { are identified. Such a study might even } \\
\text { contrast competing 'layperson' } \\
\text { constructions of tourism knowledge } \\
\text { through user generated web content. }\end{array}$ \\
\hline The archive & $\begin{array}{l}\text { The archive refers to systems of } \\
\text { statements and the rules that govern }\end{array}$ & $\begin{array}{l}\text { Understanding the archive involves an } \\
\text { interrogation of how the objects of }\end{array}$ & $\begin{array}{l}\text { Again, the specific research context will } \\
\text { dictate how the archive is defined in }\end{array}$ \\
\hline
\end{tabular}




\begin{tabular}{|c|c|c|c|}
\hline & $\begin{array}{l}\text { their formation, correlation and } \\
\text { transformation in a given place and time } \\
\text { (Nicholls, 2009) }\end{array}$ & $\begin{array}{l}\text { museum discourse can come to be used } \\
\text { (or ignored) in systems of statements. } \\
\text { For example, the museums analysed in } \\
\text { the } 2016 \text { study deploy discourses } \\
\text { according to particular laws governing } \\
\text { what can and cannot be said about, for } \\
\text { example, Soviet occupation. This } \\
\text { analysis comes into more focus the } \\
\text { further back the analyst is prepared to } \\
\text { go with a series of texts. }\end{array}$ & $\begin{array}{l}\text { tourism discourse research. The process } \\
\text { of discourse analysis is itself required to } \\
\text { define the archive. The analyst might } \\
\text { describe, for example the particular } \\
\text { discourses used to constitute a } \\
\text { particular destination in a given time (for } \\
\text { example, how was the UK marketed } \\
\text { overseas in 2017? What set of } \\
\text { statements were deployed to impose } \\
\text { limits on how the UK could come to be } \\
\text { 'known' by visitors?). Again, an } \\
\text { interrogation of narrative is required in } \\
\text { order to identify the discursive } \\
\text { structures or 'rules' that impose limits } \\
\text { on concepts, objects and places or } \\
\text { people. Ethnographic centred research } \\
\text { might seek to understand how } \\
\text { destination cultures are constructed } \\
\text { through tourism marketing discourses. }\end{array}$ \\
\hline Enunciation & $\begin{array}{l}\text { The discursive conditions under which } \\
\text { something can be said and the position } \\
\text { from which it can be said. O' Donnell } \\
\text { and Spires (2012) refer to modalities of } \\
\text { enunciation including commentary and }\end{array}$ & $\begin{array}{l}\text { The modalities of enunciation will } \\
\text { include exhibitions but also guided tours } \\
\text { and other directive visitor information } \\
\text { such as guide books and interpretive } \\
\text { narrative that accompanies the tangible }\end{array}$ & $\begin{array}{l}\text { Coles and Timothy (2004) offer a useful } \\
\text { interpretation of enunciation as the } \\
\text { space/s in which destination identity can } \\
\text { 'announce' itself. Again, the context will } \\
\text { dictate the limits, but to stay with the }\end{array}$ \\
\hline
\end{tabular}




\begin{tabular}{|c|c|c|c|}
\hline & advertisements. & $\begin{array}{l}\text { objects that are displayed (all in the } \\
\text { English language in this case). }\end{array}$ & $\begin{array}{l}\text { destination image example, the } \\
\text { discourse analyst could critique } \\
\text { 'storylines' within spaces such as } \\
\text { attractions, museums and heritage sites. } \\
\text { Relevant here are spaces where tourism } \\
\text { plays the role of a communicative } \\
\text { vehicle through which people and places } \\
\text { can reveal and legitimize themselves. } \\
\text { The growth of social media and web } 2.0 \\
\text { as spaces in which stories are } \\
\text { exchanged, and constructs contested } \\
\text { offers an abundance of fertile territory } \\
\text { to be explored by Foucauldian discourse } \\
\text { analysts. }\end{array}$ \\
\hline
\end{tabular}




\begin{tabular}{|c|c|c|c|}
\hline & & $\begin{array}{l}\text { the museum environment. This is } \\
\text { typically dependent on exposure to an } \\
\text { entire 'field' such as the fields of } \\
\text { psychiatry and of the justice system that } \\
\text { Foucault reasoned around. }\end{array}$ & $\begin{array}{l}\text { '...assortment of discourses around } \\
\text { which the (cruise) tourist gaze is } \\
\text { constructed...including the cruise } \\
\text { company, the cruise ship, marketing and } \\
\text { the voyage'. Using this reasoning, the } \\
\text { Foucauldian discourse analyst is } \\
\text { challenged to understand the vehicles of } \\
\text { discourse and how texts work together } \\
\text { to produce rarefied forms of knowledge } \\
\text { in tourism settings. Cultural heritage is a } \\
\text { particularly fertile area for apprehending } \\
\text { discursive formation as heritage sites } \\
\text { provide ontological categories for how } \\
\text { objects of discourse can come to be } \\
\text { known in 'cocooned' environments. }\end{array}$ \\
\hline Knowledge & $\begin{array}{l}\text { Refers to the discursive 'conditions of } \\
\text { possibility' for what is generally } \\
\text { understood to be objective or subjective } \\
\text { 'knowledge.' }\end{array}$ & $\begin{array}{l}\text { This is essentially how the discursive } \\
\text { practices of museums are understood as } \\
\text { knowledge. What is required here is } \\
\text { discourse analysis itself to explore the } \\
\text { discursive production of an imagined } \\
\text { Lithuania according to its deployment in } \\
\text { museums. }\end{array}$ & $\begin{array}{l}\text { Knowledge in this context 'defines the } \\
\text { way certain things are represented, } \\
\text { thought about, practiced and studied } \\
\text { (Hall, 1997:49) and for the tourism } \\
\text { discourse analyst this means challenging } \\
\text { the taken for granted representations } \\
\text { of, for example people, places and } \\
\text { cultures. Examples of research contexts } \\
\text { that might be commodious to this kind }\end{array}$ \\
\hline
\end{tabular}




\begin{tabular}{|c|c|c|c|}
\hline & & & $\begin{array}{l}\text { of critique include the construction of } \\
\text { nationhood through the marketing } \\
\text { efforts of National Tourism } \\
\text { Organisations, or the constructed sense } \\
\text { of place that is enunciated by } \\
\text { Destination Marketing Organisations. } \\
\text { Both examples offer (Wilkes (2016: 25) } \\
\text { '... cluster of ideas, images and } \\
\text { practices which provide a way of talking } \\
\text { about forms of knowledge'. Knowledge } \\
\text { in this sense is apprehended as a regime } \\
\text { of truth. }\end{array}$ \\
\hline
\end{tabular}




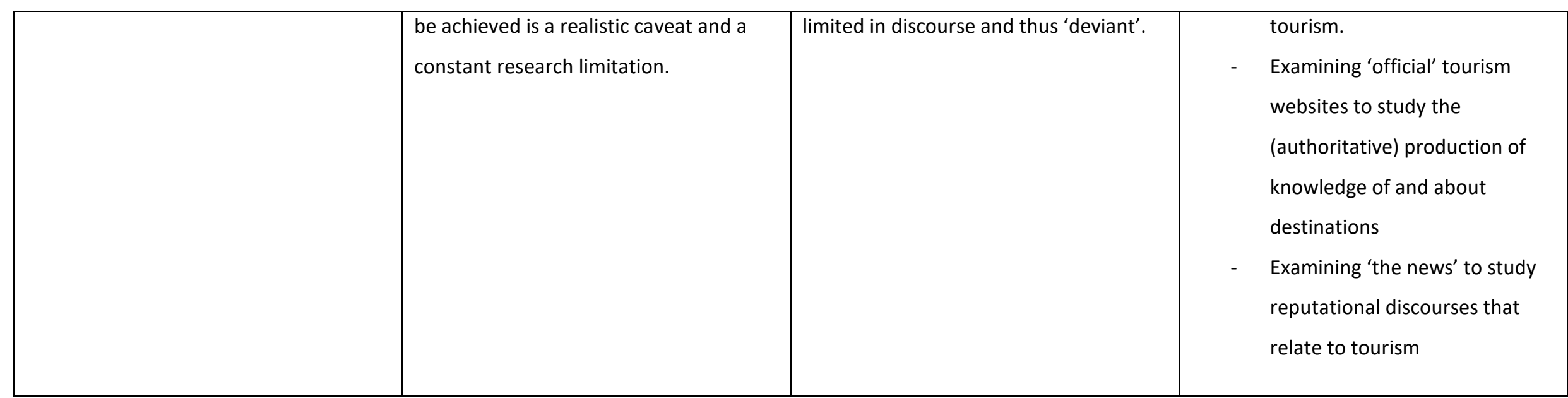


